\title{
UJI KOMPARASI NILAI GROSS PRIMARY PRODUCTIVITY (GPP) DAN KELIMPAHAN KLOROFIL-a KOLAM BUDIDAYA PEMBESARAN IKAN DENGAN PUPUK DAN TANPA PUPUK
}

\author{
Muhammad Masyarul Rusdani $^{1)}$; Muhammad Junaidi ${ }^{1)}$; Abdul Syukur ${ }^{2)}$ \\ 1) Program Studi Budidaya Perairan Universitas Mataram \\ 2) Program Studi Pendidikan Biologi Universitas Mataram \\ mm.rusdani@unram.ac.id
}

\begin{abstract}
ABSTRAK
Pemupukan dalam kegiatan budidaya perikanan bertujuan untuk meningkatkan kesuburan media pemeliharaan dengan memberikan unsur atau zat hara ke dalam tanah yang secara langsung atau tidak dapat meningkatkan produktivitas primer media. Gross Primary Productivity (GPP) dan klorofil-a (Chl-a) merupakan parameter yang biasa digunakan untuk menentukan produktivitas media pemeliharaan ikan. Pemberian pupuk pada media diduga dapat berpengaruh terhadap peningkatan produktivitas lahan, sehingga dalam penelitian ini dilakukan uji komparasi nilai GPP dan Chl-a pada kolam yang diberikan pupuk dan tanpa pupuk. Hasil penelitian menunjukkan bahwa nilai GPP dan Chl-a pada kolam yang diberikan pupuk berbeda nyata dengan kolam tanpa pupuk. Diakhir periode sampling diperoleh nilai GPP dan Chl-a berturut-turut sebesar $350.20 \mathrm{mg} \mathrm{C} / \mathrm{m}^{3} / \mathrm{jam}$ dan $400.00 \mathrm{ug} / \mathrm{L}$ pada kolam tanpa pupuk dan $484.59 \mathrm{mg}$ $\mathrm{C} / \mathrm{m}^{3} / \mathrm{jam}$ dan $592.73 \mathrm{ug} / \mathrm{L}$ pada kolam dengan pupuk. Nilai GPP dan Chl-a memiliki keterkaitan yang sangat tinggi, baik pada kolam tanpa pupuk maupun dengan pupuk. Hal ini terlihat dari nilai korelasi Pearson untuk GPP dan Chl-a pada kolam dengan pemberian pupuk 0.9811 dan 0.9389 pada kolam tanpa pemberian pupuk.
\end{abstract}

Kata kunci : pemupukan, gross primary productivity, klorofil-a.

Fertilization in aquaculture aims to increase the pond fertility by providing nutrients of soil based, which directly or indirectly may increase primary productivity. Gross Primary Productivity (GPP) and chlorophyll-a (Chl-a) are common parameters used to determine the productivity of fish pond. Fertilizing fish pond is expected to increase productivity. The data collected in this study was analyzed using comparative test for GPP and Chl-a values in pond with and without fertilizer. The result shows that the value of GPP and Chl-a in the pond with and without fertilizer are significantly different. At the end of the observation, GPP and Chl-a values were $350.20 \mathrm{mg} \mathrm{C} / \mathrm{m}^{3} / \mathrm{h}$ and 400.00 $\mathrm{ug} / \mathrm{L}$ in fish pond without fertilizer and $484.59 \mathrm{mg} \mathrm{C} / \mathrm{m}^{3} / \mathrm{h}$ and $592.73 \mathrm{ug} / \mathrm{L}$ in fish pond with fertilizer, both in the pond with and without fertilizer. Pearson correlation values for GPP and Chl-a in fish pond show that GPP and Chl-a have a very high relevance both in the pond with and without fertilizer, which are 0.9811 for pond with fertilizer and 0.9389 pond without fertilizer.

Keywords: Fertilization, gross primary productivity, chlorophyll-a.

\section{PENDAHULUAN}

Perikanan budidaya di Indonesia saat ini memiliki potensi yang sangat besar, namun pemanfaatannya belum maksimal. Keberhasilan kegiatan budidaya ikan sangat ditentukan oleh banyak faktor, diantaranya adalah metode budidaya yang digunakan, manajemen kegiatan (pakan, kesehatan dan kualitas media) dan pengetahuan pelaku budidaya itu sendiri (akuakulturis). Salah satu unsur penting dalam pengembangan budidaya perikanan adalah penggunaan metode budidaya yang tepat. Dalam peningkatan daya dukung media dapat dilakukan dengan pemberian pupuk (SNI: 01-6484.4 2000).

Pemupukan yang dilakukan dalam kegiatan budidaya perikanan bertujuan untuk memelihara atau memperbaiki kesuburan tanah dan air dengan memberikan unsur atau zat hara kedalam tanah yang secara langsung atau tidak langsung dapat menyumbang bahan makanan untuk tumbuhan (algae atau fitoplankton). Menurut Amin \& Pantjara (2002), pemupukan dimaksudkan sebagai usaha pemberian nutrien ke dalam tanah atau di kolam dengan tujuan untuk meningkatkan produktivitas primer media atau daya dukung media dalam menghasilkan makanan alami bagi mikroorganisme.

Kondisi nutrien pada kolam dengan pupuk maupun tanpa pupuk diduga dapat mempengaruhi kondisi struktur komunitas fitoplankton yang selanjutnya akan mempengaruhi pola kepadatan, keanekaragaman dan komposisi fitoplankton pada kolam dengan pemberian pupuk dan tanpa pemberian pupuk (Mahmud et al. 2012). Pemupukan memiliki implikasi yang besar untuk 
peningkatan biomassa fitoplankton yang akan berpengaruh secara langsung pada biomassa ikan (Vega et al. 2007). Ada banyak variabel uji yang dapat digunakan dalam menentukan produktivitas primer di media pemeliharaan, salah satunya adalah dengan penentuan Gross Primary Productivity (GPP) dan klorofil-a (Chl-a) untuk menentukan biomassa fitoplankton di media.

Produktivitas primer kotor (Gross Primary Productivity) adalah laju produksi primer zat organik secara keseluruhan, termasuk yang digunakan untuk respirasi, sedangkan produktivitas (Nybakken 1988). Adapun klorofil-a adalah pigmen utama yang dimiliki oleh produsen primer (organisme fotosintetik) dan berfungsi untuk menangkap cahaya sebagai sumber energi utamanya (Dawes 1981). Sehingga semakin tinggi nilai GPP maupun Klorofil-a mengindikasikan semakin tingi pula produktivitas primer di dalam media tersebut.

\section{BAHAN DAN METODE}

Penelitian ini menggunakan dua buah kolam pembesaran ikan. Sebelum pemeliharaan ikan dimulai, kolam terlebih dahulu diberikan perlakuan uji yaitu kolam A diberikan pupuk kotoran ayam dengan dosis 5 ton/ha (Khairuman \& Sudenda 2009) dan kolam B tidak diberikan pupuk. Kolam tersebut memiliki ukuran yang sama dan ditebar ikan dari jenis dan ukuran yang sama pula (ikan lele @5-8 cm). Pakan yang digunakan selama pemeliharaan ikan adalah pakan buatan (hiprovite $(\mathrm{C})$ dengan kadar protein 30-32\% secara ad satiation (sekenyangnya) sebanyak 3 kali sehari. Ikan dipelihara selama 30 hari tanpa pergantian air. Setiap 7 hari dilakukan sampling untuk parameter uji, yaitu GPP dan klorofil-a.

Pengukuran nilai GPP ditentukan dengan menggunakan metode oksigen botol gelap dan botol terang. Prinsip kerja metode ini adalah mengukur perubahan kandungan oksigen dalam botol terang dan botol gelap yang berisi sampel air setelah diinkubasi pada kolom air. Waktu inkubasi dilakukan pada saat matahari optimal yaitu pada jam 09.00 - 14.00 Wita. Prosedur pengukurannya dilakukan dengan perhitungan sebagai berikut (Parson et al. 1984) :

$$
G P P=\frac{O_{2} B T-O_{2} B G 1.000}{P Q \quad t} x 0,375
$$

Keterangan :

GPP = Fotosintesis kotor $\left(\mathrm{mg} \mathrm{C} / \mathrm{m}^{3} / \mathrm{jam}\right)$

$\mathrm{O}_{2} \mathrm{BT}=$ Oksigen terlarut Botol terang $(\mathrm{mg} / \mathrm{L})$

$\mathrm{O}_{2} \mathrm{BG}=$ Oksigen terlarut Botol gelap $(\mathrm{mg} / \mathrm{L})$

$1.000=$ Konversi liter menjadi $\mathrm{m}^{3}$

PQ =Photosintetic Quotient : 1,2 dengan asumsi hasil metabolisme dari fitoplankton.

$\mathrm{t}=$ Lama inkubasi (jam)

$0,375=$ Koefisien konversi oksigen menjadi karbon (12/32)

PQ adalah perbandingan $\mathrm{O}_{2}$ terlarut yang dihasilkan dengan $\mathrm{CO}_{2}$ yang digunakan melalui proses fotosintesis. Menurut Parson et al. (1984), nilai PQ berkisar 1,1 - 1,3 untuk organisme yang memiliki klorofil. Nilai 1,2 diperoleh dengan asumsi bahwa dalam proses fotosintesis didominasi oleh fitoplankton (mikro alga).

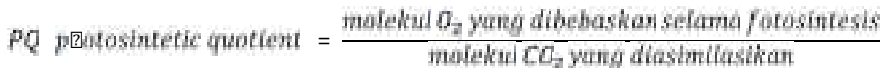

$R Q$ respiration quotient $=\frac{\text { molekul } \mathrm{CO}_{2} \text { yang dilepaskan selama respinasi }}{\text { molekui } 0_{2}^{-} \text {yang dikonsumsi }}$

Nilai PQ dan RQ untuk masing-masing jenis fitoplankton berbeda-beda. Rata-rata nilai $P Q$ dan $R Q$ untuk semua jenis fitoplankton adalah $P Q=1,2$ dan $R Q$ $=1,0$ dengan asumsi bahwa aktivitas metabolisme sebagian besar disebabkan oleh komunitas fitoplankton. Produktivitas sebagai laju produksi, secara umum dilaporkan dalam satuan gram $\mathrm{C}$ per meter persegi per hari.

Biomassa fitoplankton dapat diartikan sebagai banyaknya kloroplas per satuan luas atau volume pada saat tertentu. Selain itu akumulasi fitoplankton merupakan produk akhir pertumbuhan fitoplankton yang ditentukan dengan laju produksi biomassa. Pengukuran biomassa dinyatakan dalam jumlah miligram klorofil-a per detik. Untuk analisis biomassa fitoplankton menggunakan formulasi sebagai berikut (APHA 2005) :

$$
\text { Klorofil - a } \mu g / L=11,9 \text { A665-A750 } \times \frac{V}{L} \times \frac{1000}{S}
$$

Keterangan :

A665 = Absorban pada panjang gelombang $665 \mathrm{~nm}$

A750 = Absorban pada panjang gelombang $750 \mathrm{~nm}$

$\mathrm{V} \quad=$ Volume ekstraktor (aceton $90 \%)(\mathrm{ml})$

$\mathrm{L} \quad=$ Panjang lintasan cahaya pada cuvet $(\mathrm{cm})$

$\mathrm{S} \quad=$ Volume sampel air yang disaring $(\mathrm{ml})$

11,9= Nilai konstanta

Prosedur pengambilan sampel air (Klorofil-a)

Prosedur pengukuran klorofil-a pada fitoplankton dilakukan dengan cara sebagai berikut (Boyd 1990) :

1. Air sampel sebanyak $150 \mathrm{ml}$ disaring menggunakan filter milipore yang telah dibasahi $1 \mathrm{ml}$ larutan magnesium karbonat dengan bantuan vacuum syringe atau vacuum pump.

2. Membran filter yang mengandung klorofil-a dilipat empat kali sampai menjadi lipatan kecil, lalu dimasukkan ke dalam tissue grinder kemudian ditambah $5 \mathrm{ml}$ aseton 90\%. Kemudian digerus sampai hancur merata. Setelah itu ditambahkan lagi $3,5 \mathrm{ml}$ aseton yang sama dan dilanjutkan penggerusan sampai semua bagian filter hancur.

3. Larutan selanjutnya dipindah ke dalam tabung reaksi untuk disentrifus, tutup dengan penutup plastik, beri label. Sentrifus tabung-tabung ekstraksi pada putaran $3.000 \mathrm{rpm}$ selama 15 menit.

4. Substansi hasil sentrifugasi terbagi menjadi dua, yaitu supernatan dan pelet. Supernatan adalah substansi hasil sentrifugasi yang memiliki bobot jenis yang lebih rendah. Posisis dari substansi ini 
berada pada lapisan atas dan warnanya lebih jernih. Sementara pelet adalah substansi hasil sentrifugasi yang memiliki bobot jenis yang lebih tinggi. Posisisnya berada pada bagian bawah (berupa endapan) dan warnanya lebih keruh. Supernatan selanjutnya diukur dengan spektrofometer sesuai dengan panjang gelombang yang diinginkan.

\section{Analisis Data}

Data GPP dan Chl-a yang diperoleh dalam penelitian ini selanjutnya dianalisis menggunakan Pearson correlation dan regresi sederhana untuk mengukur tingkat keeratan data GPP dengan Chl-a. Disamping itu, dilakukan juga analisis data komparasi antara kolam dengan pupuk maupun tanpa pupuk menggunakan uji t-paired two sample for means pada taraf nyata (a) $5 \%$.

\section{HASIL DAN PEMBAHASAN}

Sistem budidaya yang banyak berkembang di Indonesia adalah masih mengandalkan pakan alami di media dalam upaya mendukung pertumbuhan ikan. Sehingga, tingginya keberadaan pakan alami seperti fitoplankton, bentos dan perifiton secara langsung akan berpengaruh dalam produktivitas primer dan selanjutnya dalam pertumbuhan ikan (Chattopadhyay 2004). Kondisi tanah dasar media pemeliharaan memegang peranan penting dalam transformasi nutrien, terutama dalam proses transformasi nutrien dari pupuk dan kelebihan nutrien dari sisa pakan (Banerjee et al. 2010).

Hasil pengamatan nilai Gross Primary Productivity (GPP) menunjukkan hasil yang signifikan antara kolam yang diberikan pupuk dengan tanpa pupuk $(p=0.017)$, demikian juga dengan konsentrasi klorofil-a (Chl-a) $(p=0.008)$. Nilai GPP dan konsentrasi Chl-a pada kolam yang diberikan pupuk lebih tinggi dibandingkan dengan kolam yang tanpa diberikan pupuk. Berikut ada lah hasil pengamatan selama penelitian berlangsung terhadap nilai GPP dan Chl-a media pemeliharaan (Gambar 1 dan 2).

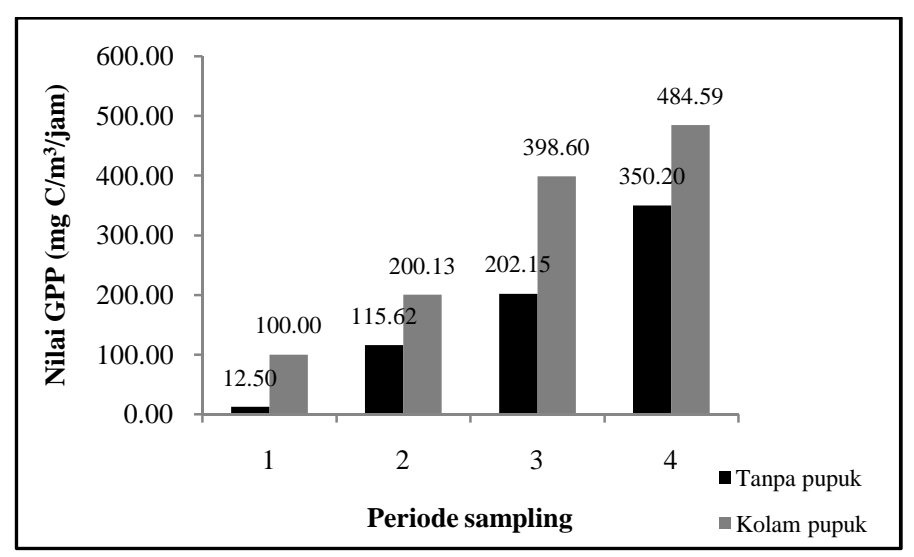

Gambar 1. Nilai GPP pada kolam dengan pemberian pupuk dan tanpa pemberian pupuk selama periode sampling.

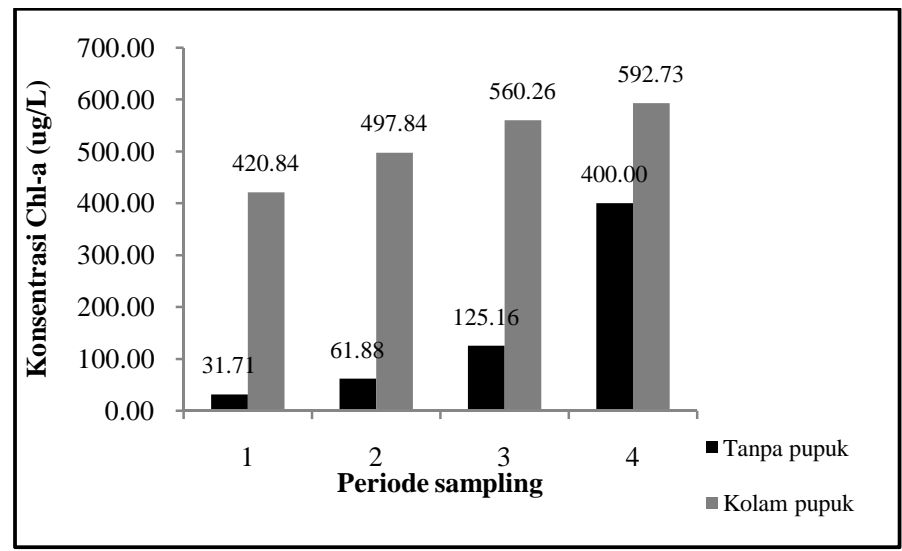

Gambar 2. Konsentrasi Chl-a pada kolam dengan pemberian pupuk dan tanpa pemberian pupuk selama periode sampling.

Diakhir periode sampling diperoleh nilai GPP dan Chl-a berturut - turut sebesar $350.20 \mathrm{mg} \mathrm{C} / \mathrm{m}^{3} / \mathrm{jam}$ dan $400.00 \mathrm{ug} / \mathrm{L}$ pada kolam tanpa pupuk dan $484.59 \mathrm{mg}$ $\mathrm{C} / \mathrm{m}^{3} / \mathrm{jam}$ dan $592.73 \mathrm{ug} / \mathrm{L}$ pada kolam dengan pupuk. Tinggginya nilai GPP dan Chl-a pada kolam dengan pupuk jika dibandingkan dengan kolam tanpa pupuk menunjukkan bahwa pemberian pupuk pada media pemeliharaan dapat meningkatkan produktivitas primer media tersebut.

Tingginya produktivitas primer yang tercermin pada nilai GPP memiliki keeratan hubungan yang sangat tinggi. Hal ini terlihat dari hasil pengamatan korelasi Pearson, yaitu nilai korelasi untuk GPP dan Chl-a pada kolam dengan pemberian pupuk 0.9811 dan sebesar 0.9389 pada kolam tanpa pemberian pupuk. Boyd \& Tucker (1998) menyebutkan bahwa lingkungan budidaya (media pemeliharaan) akan mempengaruhi keberadaan komunitas organisme yang dapat hidup didalamnya. Tingginya produktivitas primer yang tercermin dalam GPP dapat meningkatkan biomassa mikro alga atau fitoplankton (biotic load/all biomass).

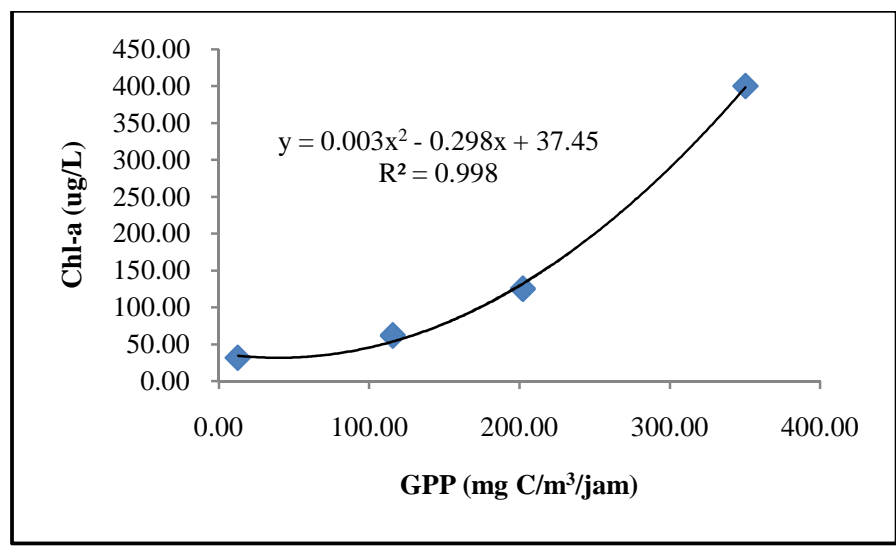

Gambar 3. Hubungan antara nilai GPP dan Chl-a pada kolam dengan tanpa pemberian pupuk selama periode sampling. 


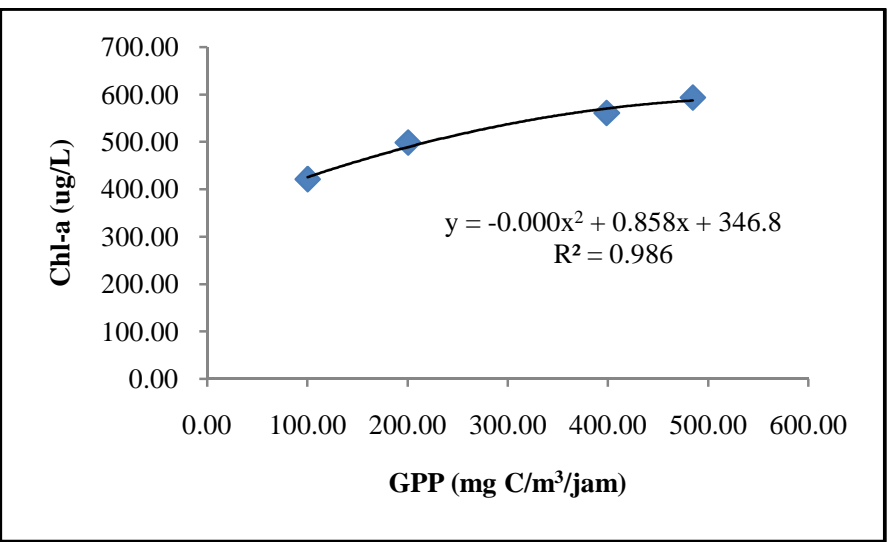

Gambar 4. Hubungan antara nilai GPP dan Chl-a pada kolam dengan pemberian pupuk selama periode sampling.

Hubungan antara nilai GPP dan Chl-a pada kolam tanpa pemberian pupuk, mengikuti persamaan regresi polynomial $\mathrm{y}=0.0038 \mathrm{x}^{2}-0.2988 \mathrm{x}+37.454$ dengan koefisien determinasi $\mathrm{R}^{2}=0.9985$ (Gambar 3). Hal ini menunjukkan bahwa $99.85 \%$ yang konsenterasi Chl-a (biomassa fitoplankton) dipengaruhi oleh nilai GPP pada media tersebut. Adapun hubungan kedua nilai ini pada kolam dengan pemberian pupuk, mengikuti persamaan regresi polynomial $\mathrm{y}=-0.0007 \mathrm{x}^{2}+0.8589 \mathrm{x}+346.88$ dengan koefisien determinasi $\mathrm{R}^{2}=0.9865$ (Gambar 4). Hal ini menunjukkan bahwa $98.65 \%$ Chl-a pada kolam dengan pupuk dipengaruhi oleh nilai GPP.

\section{KESIMPULAN}

Berdasarkan hasil penelitian dan pembahasan yang terbatas pada lingkup penelitian ini, dapat disimpulkan bahwa kolam dengan pemberian pupuk memiliki nilai produktivitas primer yang lebih tinggi dibandingkan dengan kolam tanpa pemberian pupuk. Hal ini tercermin dari nilai GPP dan Chl-a yang lebih tinggi jika dibandingkan dengan kolam tanpa pupuk. Tingginya nilai produktivitas primer diharapkan dapat menyediakan pakan alami sehingga dapat menunjang pertumbuhan ikan yang dibudidaya.

\section{DAFTAR PUSTAKA}

[APHA] American Public Health Association. 2005. Standard methods for the examination of water and waste water, $21^{\text {st }}$ edition. Washington, DC (US): American Public Health Association.

Banerjee A., Chattopadhyay \& CE. Boyd. 2010. Soil system-based approach: a tool for fish pond fertilization. Better Crops, 94 (1) : 22-24.

Boyd CE. 1990. Water quality in pond for aquaculture. Alabama (US) : Brimingham Publishing Co. 482p.

Boyd CE \& CS Tucker. 1998. Pond aquaculture water q uality management. Kluwe Academic Publishers, Boston, Massachusetts, USA.

Chattopadhyay GN. 2004. Fertilization. News 49(4): $87-$ 93
Dawes, CJ. 1981. Marine Botany. John Willey \& Sons. New York. 628 pp.

Khairuman \& D. Sudenda, 2009. Budidaya Patin secara Intensif. Jakarta (ID): PT. Agromedia Pustaka.

Mahmud S., Aunurohim, \& ITD. Tjahyaningrum, 2012. Struktur Komunitas Fitoplankton pada Tambak dengan Pupuk dan Tambak Tanpa Pupuk di Kelurahan Wonorejo, Surabaya, Jawa Timur. Jurnal Sains dan Seni ITS, (1): 10-15.

Nybakken, J.W. 1988. Biologi Laut. In: Noviana V.A. \& M. Izzati. 2009. Kandungan klorofil, fikoeritrin dan karaginan pada rumput laut Eucheuma spinosum yang ditanam pada kedalaman yang berbeda. Anatomi Fisiologi, XVII (2) : 55-63.

Parsons, T.R.; M. Takahashi \& B. Habgrave. 1984. Biological Oceanographic Processes, $3^{\text {th }}$ edition. Oxford: Pergamon Press. 330p.

SNI : 01-6484.2-2000. Benih Ikan Lele Dumbo (Clarias gariepinus $x$ C. Fuscus) Kelas Benih Sebar. Jakarta (ID): BSN

Vega C., C. Jambrina, R. Saja, E. Becares, C. Fernández, \& M. Fernández, 2007. Aspectos limnológicos de estanques para la producción intensiva de tenca (Tiricatinca). Limnética,. (26): 173-182. 